\title{
Addressing Theoretical Gaps in Positive \\ Youth Development for Diverse Youth:
}

University of California

Agriculture and Natural Resources

4-H Youth Development Program

\author{
FACT SHEET FOR THE \\ 4-H Youth Development Program
}

ANR Publication 8576 | August 2017

http://anrcatalog.ucanr.edu

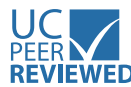

\section{THE REALITY}

The UC ANR 4-H Youth Development Program (YDP) embraces positive youth development (PYD) as a theoretical approach for engaging youth and helping them reach their full potential.
KALI H. TRZESNIEWSKI, Associate Director of Research for the Statewide 4-H Youth Development Program and Specialist in Cooperative Extension, Davis Department of Human Ecology, University of California, Davis; and UC ANR Diversity in Youth Development Workgroup

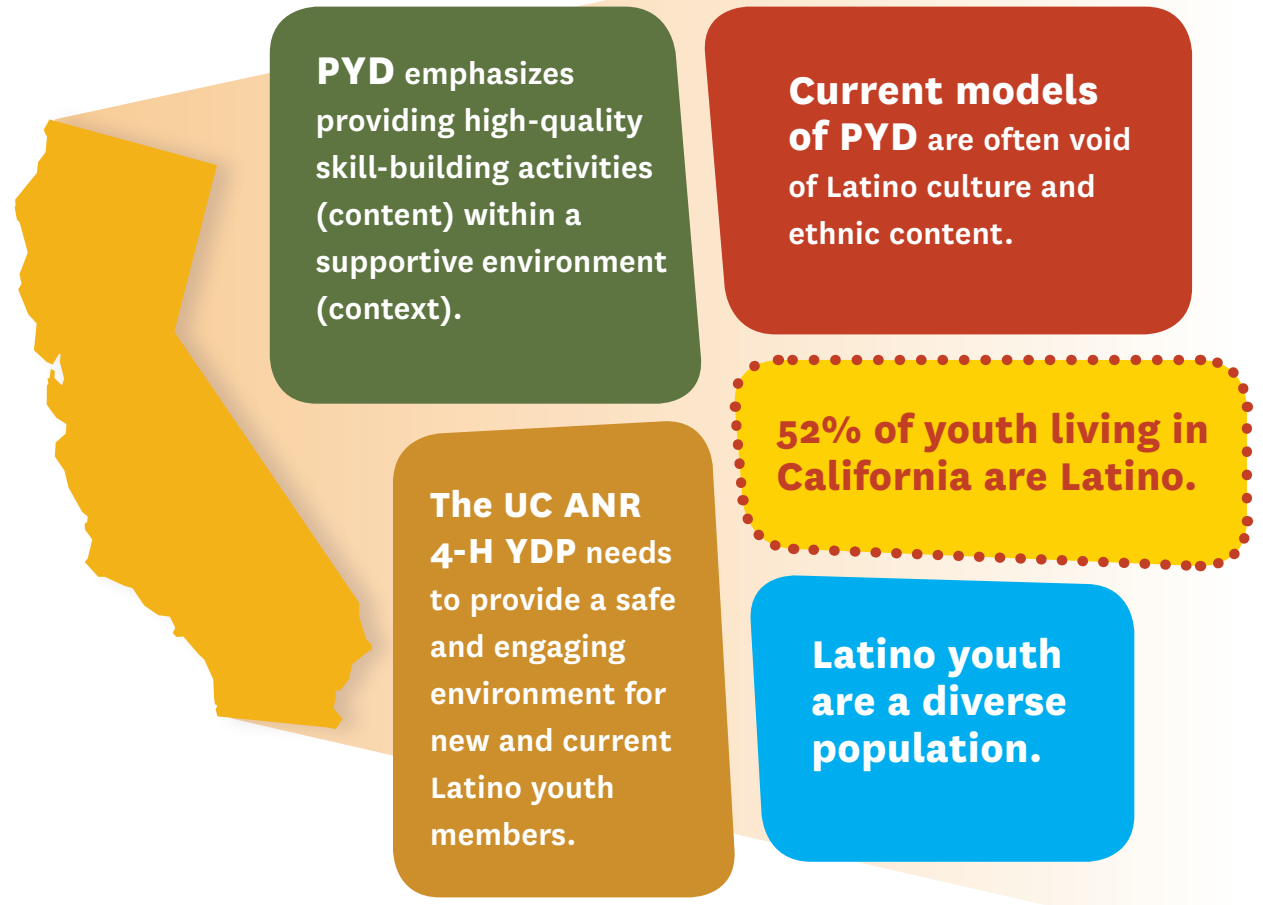

Navigating Biculturalism and Acculturation

"Latino youth benefit from settings that understand and support their unique cultural and linguistic heritage, particularly the challenges and richness of navigating more than one language and culture [biculturalism]...[and] support acculturation: awareness of an ongoing negotiation between cultures and languages"

(Erbstein and Fabionar 2014) 


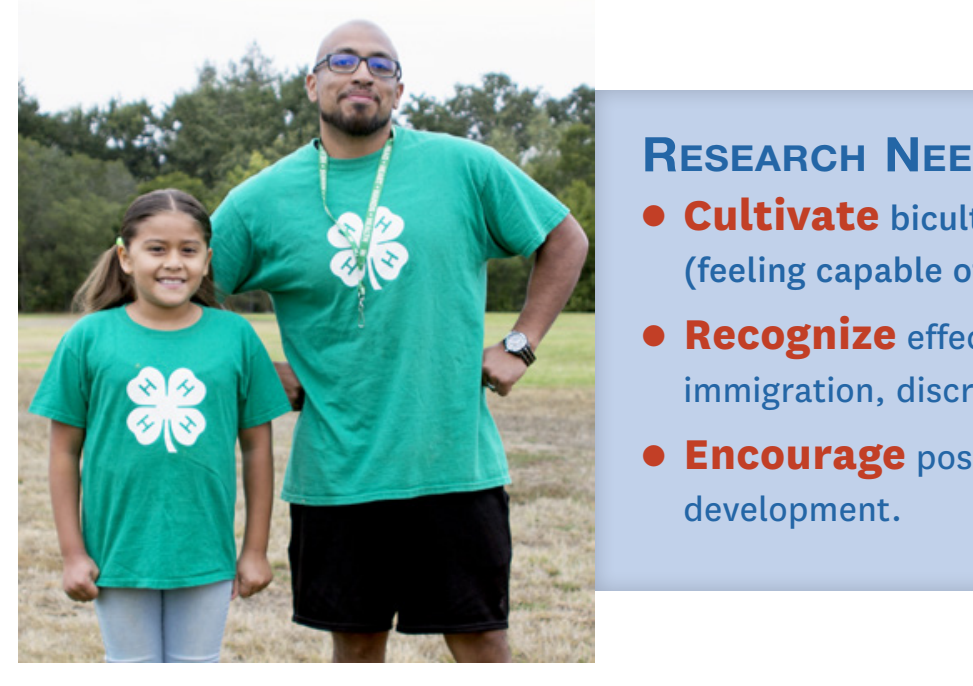

\section{Recommendations}

Gain a deeper understanding of the cultural characteristics of Latino youth across diverse contexts.

- Understand the concepts of racialization, panethnicity, globalization, and transnationalism, and how Latino youth may experience these contexts.

- Gain deeper knowledge of the cultural dimensions of immigration, language, discrimination, and poverty experienced by Latino youth and families.

- Learn how Latino youth navigate through and contend with immigration, discrimination, and poverty.

- Understand the cultural similarities and differences among Latino familial and ethnic relationships.

Adapt and evaluate programs.

- Develop UC ANR 4-H YDPs that adapt the positive youth development model to reflect the needs of diverse youth and their families.

- Using community participatory approaches, identify valued goals for positive development in diverse communities, and incorporate them into 4-H evaluation.

- Prepare UC ANR 4-H volunteers to create safe environments while working with diverse populations.

- Encourage racial and ethnic identity development for all youth, creating safe environments for cultural sharing.

- Explore personal assumptions of PYD, identify the cultural concepts that shape these views, and reflect on the ways these ideas influence professional practices.

\section{MORE INFORMATION}

Positive youth development frameworks.

See Spencer, M., D. Dupree, and T. Hartmann. 1997. Phenomenological variant of ecological systems theory (PVEST). Development and Psychopathology 9:817-833.

\section{Sociocultural approaches to learning and} development. See Rogoff, B. 2003. The cultural nature of human development. Oxford, UK: Oxford University Press.

\section{Critical race theory (CRT) and community} cultural wealth. See Yosso, T. J. 2005. Whose culture has capital? A critical race theory discussion of community cultural wealth. Race Ethnicity and Education 8:69-91.

Youth activism. See Middaugh, E., J. Conner, D. Donahue, A. Garcia, U. J. Kahne, and B. Kirshner. 2012. Service and activism in the digital age supporting youth engagement in public life. DML Central Working Papers. Irvine, CA: Digital Media and Learning Research Hub, University of California Humanities Research Institute.

\section{References}

Erbstein, N., and J. Fabionar. 2014. Latin@youth participation in youth development programs: A review of research. UCCE Santa Clara County website, http://cesantaclara.ucanr.edu/ files/261436.pdf.

\section{Suggested citation}

Trzesniewski, K. H., and UC ANR Diversity in Youth Development Workgroup. 2017. Addressing Theoretical Gaps in Positive Youth Development for Diverse Youth: Fact Sheet for the 4-H Youth Development Program. Oakland: University of California Division of Agriculture and Natural Resources Publication 8576. 


\section{Please address correspondence to}

University of California,

Agriculture and Natural Resources

California State 4-H Office

2801 Second Street

Davis, CA 95618-7774

Phone: (530) 750-1334

Email: ca4h@ucanr.edu

\section{FOR FURTHER INFORMATION}

To order or obtain ANR publications and other products, visit the ANR Communication Services online catalog at http://anrcatalog. ucanr.edu/ or phone 1-800-994-8849. You can also place orders by mail or FAX, or request a printed catalog of our products from

University of California

Agriculture and Natural Resources

Communication Services

2801 Second Street

Davis, CA 95618

Telephone 1-800-994-8849

E-mail: anrcatalog@ucanr.edu

(C)2017 The Regents of the University of California. This work is licensed under the Creative Commons AttributionNonCommercial-NoDerivatives 4.0 International License. To view a copy of this license, visit http://creativecommons.org/ licenses/by-nc-nd/4.0/ or send a letter to Creative Commons, PO Box 1866, Mountain View, CA 94042, USA.

\section{Publication 8576}

ISBN-13: 978-1-60107-986-2

The University of California, Division of Agriculture and Natural Resources (UC ANR) prohibits discrimination against or harassment of any person in any of its programs or activities on the basis of race, color, national origin, religion, sex, gender, gender expression, gender identity, pregnancy (which includes pregnancy, childbirth, and medical conditions related to pregnancy or childbirth), physical or mental disability, medical condition (cancer-related or genetic characteristics), genetic information (including family medical history), ancestry, marital status, age, sexual orientation, citizenship, status as a protected veteran or service in the uniformed services (as defined by the Uniformed Services Employment and Reemployment Rights Act of 1994 [USERRA]), as well as state military and naval service.

UC ANR policy prohibits retaliation against any employee or person in any of its programs or activities for bringing a complaint of discrimination or harassment. UC ANR policy also prohibits retaliation against a person who assists someone with a complaint of discrimination or harassment, or participates in any manner in an investigation or resolution of a complaint of discrimination or harassment. Retaliation includes threats, intimidation, reprisals, and/or adverse actions related to any of its programs or activities.

UC ANR is an Equal Opportunity/Affirmative Action Employer. All qualified applicants will receive consideration for employment and/or participation in any of its programs or activities without regard to race, color, religion, sex, national origin, disability, age or protected veteran status.

University policy is intended to be consistent with the provisions of applicable State and Federal laws.

Inquiries regarding the University's equal employment opportunity policies may be directed to: John Sims, Affirmative Action Contact and Title IX Officer, University of California, Agriculture and Natural Resources, 2801 Second Street, Davis, CA 95618, (530) 750-1397. Email: jsims@ucanr.edu. Website: http://ucanr. edu/sites/anrstaff/Diversity/Affirmative_Action/.

An electronic copy of this publication can be found at the ANR Communication Services catalog website, http://anrcatalog.ucanr. edu/.

UC This publication has been anonymously peer PEER reviewed for technical accuracy by University of California scientists and other qualified professionals. This review process was managed by ANR Associate Editor for Human and Community-Youth Development Katherine Soule.

web-08/17-LR/CR

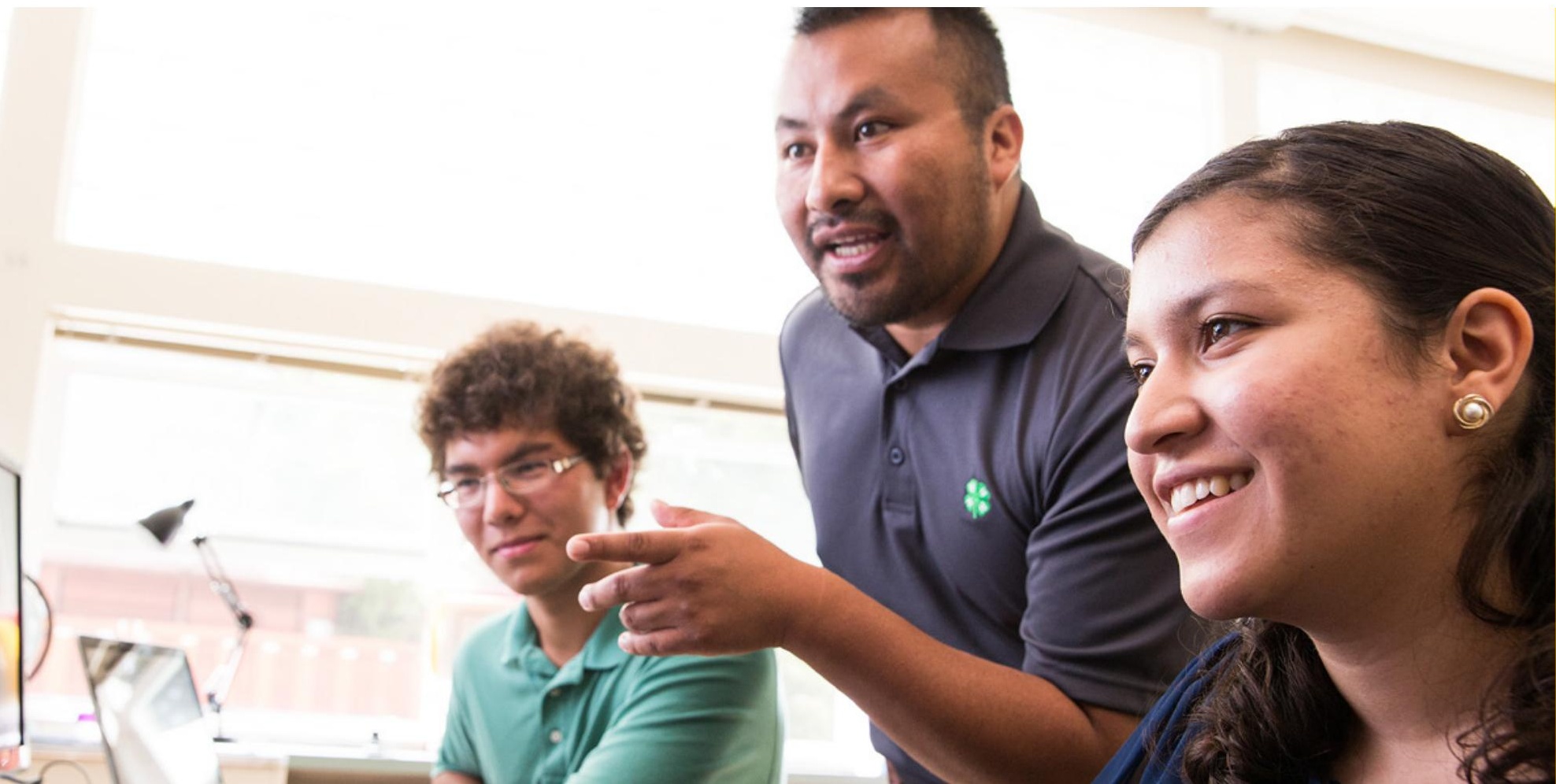

